\title{
The effect of cognitive task on ankle movement variability in athletes with Functional Ankle Instability
}

\author{
Sanam Tavakoli ${ }^{1}$, Saeed Forghany ${ }^{1,2^{*}}$, Christopher Nester ${ }^{2}$, Akram Jamali ${ }^{1}$, Khadijeh Bapirzadeh ${ }^{1}$ \\ From 4th Congress of the International Foot and Ankle Biomechanics (i-FAB) Community \\ Busan, Korea. 8-11 April 2014
}

\section{Background}

Gait has been generally viewed as a largely automated motor task, requiring minimal higher-level cognitive input. Increasing evidence, however, suggest that attention demanding cognitive tasks to disturb gait $[1,2]$. Movement variability may influence joint stability and increase the risk of "giving way" at the ankle in individuals with functional ankle instability (FAI)[3]. The purpose of this study was to investigate the effect of dual-tasking on ankle movement variability in athletes with FAI.

\section{Methods}

21 athletes (age $25.57 \pm 4.77$ years) with clinically diagnosed FAI were recruited. All participants completed 5 trials of normal walking and 5 trials of normal walking while performing a cognitive task. The cognitive task consisted of subtracting seven from a randomly selected number between 11 and 99 repeatedly whilst walking. Three dimensional rotations of the affected ankle (measured by an eight-camera motion capture system at
$100 \mathrm{~Hz}$ ) were calculated by visual3D during gait cycles. Between trials variability of ankle rotations time curves during stance phase and during $200 \mathrm{~ms}$ before and after heel strike were calculated using the coefficient of multiple correlations (CMC) and intraclass correlation (ICC)

\section{Results}

The results indicate that mean $\mathrm{CMC}$ was decreased during dual task condition in the sagittal and frontal planes. This was statistically significant in frontal plane during $200 \mathrm{~ms}$ before and after heel strike $(\mathrm{p}<0.05)($ Table 1$)$. There was reduction in ICC magnitude in dual-task condition compared to single task in $200 \mathrm{~ms}$ before heel strike (Table 2).

\section{Conclusion}

The athletes with FAI demonstrated greater ankle movement variability during dual task condition which may indicate diminished neuromotor control. Cognitive load may increase episodes of ankle instability in these athletes.

Table 1 Mean CMC during different conditions and periods of time.

\begin{tabular}{llll}
\hline & & Single-Task & Dual-Task \\
\hline \multirow{2}{*}{$200 \mathrm{~ms}$ before and after $\mathrm{HS}^{\mathrm{a}}$} & Frontal plane & $0.9529 \pm 0.029$ & $0.9270 \pm 0.0444^{*}$ \\
\cline { 2 - 3 } & Sagittal plane & $0.9505 \pm 0.042$ & $0.9373 \pm 0.046$ \\
\cline { 2 - 3 } & Transverse plane & $0.8530 \pm 0.150$ & $0.8539 \pm 0.140$ \\
\hline HS-TO $^{\mathrm{b}}$ & Frontal plane & $0.9396 \pm 0.042$ & 0.91150 .092 \\
\cline { 2 - 3 } & Sagittal plane & $0.9842 \pm 0.019$ & $0.9825 \pm 0.022$ \\
\cline { 2 - 3 } & Transverse plane & $0.9228 \pm 0.092$ & $0.9274 \pm 0.072$ \\
\hline
\end{tabular}

${ }^{a}$ Heel strike. ${ }^{b}$ Toe off. ${ }^{*} \mathrm{P}<0.05$

\footnotetext{
* Correspondence: Saeed_forghany@rehab.mui.ac.ir

${ }^{1}$ Musculoskeletal Research Centre, Isfahan University of Medical Sciences, Iran

Full list of author information is available at the end of the article
} 
Table 2 ICC in 3planes during different conditions

\begin{tabular}{|c|c|c|c|}
\hline & & Single-Task & Dual-Task \\
\hline \multirow[t]{3}{*}{$200 \mathrm{~ms}$ before $\mathrm{HS}^{\mathrm{a}}$} & Frontal plane & 0.964 & 0.960 \\
\hline & Sagittal plane & 0.943 & 0.710 \\
\hline & Transverse plane & 0.934 & 0.914 \\
\hline \multirow[t]{3}{*}{$\overline{\mathrm{HS}}$} & Frontal plane & 0.968 & 0.975 \\
\hline & Sagittal plane & 0.879 & 0.907 \\
\hline & Transverse plane & 0.756 & 0.908 \\
\hline \multirow[t]{3}{*}{$200 \mathrm{~ms}$ after HS } & Frontal plane & 0.958 & 0.909 \\
\hline & Sagittal plane & 0.950 & 0.949 \\
\hline & Transverse plane & 0.809 & 0.973 \\
\hline \multirow[t]{3}{*}{$\mathrm{TO}^{\mathrm{b}}$} & Frontal plane & 0.911 & 0.930 \\
\hline & Sagittal plane & 0.882 & 0.898 \\
\hline & Transverse plane & 0.924 & 0.903 \\
\hline
\end{tabular}

a Heel strike. ${ }^{\mathrm{b}}$ Toe off. ${ }^{*} \mathrm{P}<0.05$

\section{Competing interests}

Nester declares a personal commercial interest in the insoles tested in this study.

\section{Authors' details}

'Musculoskeletal Research Centre, Isfahan University of Medical Sciences, Iran. ${ }^{2}$ Centre for Health Sciences Research, University of Salford, UK.

Published: 8 April 2014

\section{References}

1. Abbud GA, Li KZ, DeMont RG: Attentional requirements of walking according to the gait phase and onset of auditory stimuli. Gait \& posture 2009, 30(2):227-32.

2. Al-Yahya E, Dawes H, Smith L, Dennis A, Howells K, Cockburn J: Cognitive motor interference while walking: a systematic review and metaanalysis. Neuroscience and biobehavioral reviews 2011, 35(3):715-28.

3. Brown CN, Padua DA, Marshall SW, Guskiewicz KM: Variability of motion in individuals with mechanical or functional ankle instability during a stop jump maneuver. In Clinical biomechanics. Volume 24. Bristol, Avon; 2009:(9):762-8.

doi:10.1186/1757-1146-7-S1-A90

Cite this article as: Tavakoli et al:: The effect of cognitive task on ankle movement variability in athletes with Functional Ankle Instability.

Journal of Foot and Ankle Research 2014 7(Suppl 1):A90.

\section{Submit your next manuscript to BioMed Central} and take full advantage of:

- Convenient online submission

- Thorough peer review

- No space constraints or color figure charges

- Immediate publication on acceptance

- Inclusion in PubMed, CAS, Scopus and Google Scholar

- Research which is freely available for redistribution

Submit your manuscript at www.biomedcentral.com/submit
C Biomed Central 